\section{Primary biliary cirrhosis and chronic active hepatitis in two sisters}

We report the cases of two elderly sisters, one with primary biliary cirrhosis and the other with chronic active hepatitis, with concurrent myxoedema. Screening of 23 relatives showed 14 to have serum autoantibodies.

\section{Case reports}

Case 1-A 72-year-old obese woman presented in March 1974 with vertigo. She had a sallow complexion and looked myxoedematous but did not have a goitre. Ankle oedema was present but there was no ascites. A firm tender liver was palpable $4 \mathrm{~cm}$ below the costal margin. The spleen was not palpable. Plasma alkaline phosphatase was $205 \mathrm{IU} / 1$ but the results of other liver function test were normal. Thyroid function tests indicated hypothyroidism. Liver biopsy showed changes associated with primary biliary cirrhosis at a fairly late stage interspersed with areas of near-normal tissue. She was strongly positive for mitochondrial antibodies ( $1 / 64$ by complement fixation; $1 / 320$ by immunofluorescence) but negative for smooth-muscle antibodies, hepatitis $\mathrm{B}$ antigen ( $\mathrm{HBAg}$ ), and antinuclear factor. Thyroid antibodies were present in low titre.

Case 2-The patient's 70-year-old sister presented in March 1974 with right hypochondrial pain. She was found to be slightly jaundiced, with a tender liver palpable $4 \mathrm{~cm}$ below the costal margin. The spleen was not enlarged, no ascites was detected, and there were no spider naevi. Plasma bilirubin was $63 \mathrm{IU} / 1$, alkaline phosphatase $115 \mathrm{IU} / 1$, gammaglutamyl transpeptidase $250 \mathrm{IU} / 1$, aspartate transaminase $138 \mathrm{IU} / 1$, and albumin $29 \mathrm{~g} / \mathrm{l}$; globulins were $61 \mathrm{~g} / 1$ (gammaglobulins raised); and antinuclear factor was present. Antinuclear antibodies (1/80), smooth-muscle antibodies $(1 / 20)$, and anti-DNA antibodies were detected but mitochondrial antibodies and $\mathrm{HBAg}$ were not. Tests for thyroid precipitin, tanned red cell agglutination and microsomal haemagglutination gave positive results. Liver biopsy showed chronic active hepatitis with a micronodular cirrhosis.

\section{Family history}

The father of the two patients had died at the age of 29 from pernicious anaemia and the mother aged 75 from heart failure. One brother had emigrated to Australia but was presumed to be well. Another brother was healthy and serum investigations showed no autoantibodies. The remaining sister had a goitre and gastric parietal cell, thyroglobulin, antinuclear, smooth-muscle, and thyroid microsomal antibodies (see figure). All five children of the first patient were found to have thyroid or parietal cell antibodies or both. Two daughters had thyrotoxicosis and renal disease respectively. Of the two sons, one had severe asthma and the other polycythaemia. Four of the five children of the second patient were screened and in none were any autoantibodies found. One had a congenital heart defect, another psoriasis, and a daughter had severe renal disease, which had necessitated nephrectomy a few years earlier. Two of the children of the third sister had normal liver function values, but both were weakly positive for thyroglobulin and gastric parietal cell antibodies. Five of the nine grandchildren tested were weakly positive for thyroid autoantibodies. One was also weakly positive for smooth-muscle antibodies. A first cousin who had married a daughter of the first patient was found to be weakly positive for smoothmuscle antibodies.

\section{Comment}

Primary biliary cirrhosis has previously been reported in sisters $^{1}$ and in two brothers. ${ }^{3}$ Galbraith et $a l^{4}$ found abnormal immunoglobulin levels in almost half of the relatives of patients with primary biliary cirrhosis and chronic active hepatitis. Primary biliary cirrhosis and chronic active hepatitis have not, however, previously been found together in the same family. Screening of 23 relatives in this family showed 14 to have autoantibodies to various tissues, providing further evidence of a genetic predisposition.

${ }^{1}$ Chohan, M R, Gut, 1974, 14, 213.

2 Walker, J G, et al, British Medical fournal, 1972, 1, 146.

${ }^{3}$ Brown, R, Clark, M L, and Doniach, D, Postgraduate Medical fournal, $1975,51,110$.

4 Galbraith, R M, et al, New England Fournal of Medicine, 1974, 290, 63.

Department of Medicine, Llandough Hospital, Penarth, South Glamorgan

MAIR WILLIAMS, BSC, medical student

P M SMITH, MD, MRCP, senior lecturer and consultant physician

The Middlesex Hospital, London WC1

DEBORAH DONIACH, MD, FRCP, professor of clinical immunology

Family tree of propositi (ages given in years). $\mathrm{MA}=$ Mitochondrial antibodies. $\mathrm{S}=$ Smooth-muscle antibodies. $\mathrm{DNA}=$ Anti-DNA antibodies. $\mathrm{N}=$ Anti-nuclear antibodies. $\mathrm{G}=\mathrm{Gastric}$ parietal cell antibodies. $\mathrm{T}=$ Thyroglobulin antibodies. $\mathbf{F Z}=$ Thyroid microsomal antibodies. $\mathrm{PBC}=$ Primary biliary cirrhosis. $\mathrm{CAH}=$ Chronic active hepatitis. $\mathrm{PA}=$ Pernicious anaemia. $\mathrm{CHD}=$ Congenital heart disease. 